\title{
ELECTRONIC NOSE FOR IDENTIFICATION OF LUNG DISEASES
}

\author{
V. Ogorodnik ${ }^{1}$, J. Kleperis ${ }^{1}$, \\ I. Taivans ${ }^{2}$, N. Jurka ${ }^{2}$, M. Bukovskis ${ }^{3}$ \\ ${ }^{1}$ Institute of Solid StatePhysics, University of Latvia, \\ 8 Kengaraga St., Riga, LV-1021, LATVIA \\ ${ }^{2}$ Faculty of Medicine of University of Latvia, \\ 19 Rainis Blvd., Riga, LV-1050, LATVIA \\ ${ }^{3}$ Institute of Experimental Clinical medicine of University of Latvia, \\ 4 O. Vaciesa St., LV-1004, Riga, LATVIA
}

\begin{abstract}
In the paper, the authors analyze the preliminary results of testing a classical gas sensing instrument - the electronic nose (a metal oxide transistor sensor of chemical substances) in a hospital where patients with different lung diseases are treated. To reveal the correlation between the amplitudes of the sensor's responses and the patients' diagnoses, different statistical analysis methods have been used. It is shown that the lung cancer can easily be discriminated from other lung diseases if short breath sampling and analysis time (less than $1 \mathrm{~min}$ ) is used in the test. Volatiles obtained from a breath sample of a patient with lung cancer give the major contribution to the responses of different e-nose sensors, so in these cases highly precise identification could be achieved.
\end{abstract}

\section{INTRODUCTION}

Electronic nose technology has been developed over the last two decades in the framework of an interdisciplinary science between olfactometry (measuring the odour intensity), olfactronics (revealing and analyzing the odours), biology, chemistry, physics, electronics and informatics. The ultimate idea was to develop an electronic equivalent of the biologic smell organ - the e-nose. It has well been recognized since 1990-ies [1] that there is a great potential in applying the e-nose technology in medicine. Typical lung cancer is often silent in its early stages, and first symptoms usually are non-specific [2]. Therefore, lung cancer is mostly diagnosed at an advanced stage, when therapy is less successful [3]. There are many techniques used in the diagnostics of lung cancer, most of them being based on the expensive and invasive testing that can cause complications. For this reason, an accurate, inexpensive, non-invasive test would be a welcome addition to the current diagnostic tools. Quick analysis and identification of the lung disease is an important factor of the patient's recovery. The interest in new diagnostic methods using simple, chip apparatus and complex data analysis supported by thorough disease description, its evolution and changes in the therapy process - is running up in the last time [4-6]. Also, the request for online diagnostics methods is urgent nowadays. 
Metabolic changes within lung cells can lead to changes in the production of different volatile organic compounds [6] which may be detected in the samples of exhaled breath. Numerous studies (see, e.g. [7, 8]) have evaluated the ability of gas chromatography and mass spectroscopy (GC-MS) to identify unique patterns of volatile organic compounds in the breath of individuals with lung cancer. However, GC-MS systems are expensive and require skill operators and qualified expert interpretation. They are difficult to use as a screening or quick diagnosis test. Application of the e-nose method for detecting unique patterns of volatile organic compounds (VOCs) could permit a broader application of breath testing for the diagnostics of lung cancer [1,4-6]. For this purpose, different gaseous chemical sensing and identification devices have been developed [1] that can detect changes in the resistance, potential, optical properties, mass, etc., all of them being able to detect the patterns of odorant molecules. The sampling time of the known devices exceeds 10 minutes [4-6].

The aim of this investigation was to identify odour characteristics for lung cancer of lung disease patients by comparing breath patterns of specific lung's diseases, and by comparing such patterns for patients before surgical operation (removal of a sick part of the lung) and after that. In distinction from the previous results published in scientific reviews, we used short sampling times - less than one minute. Based on the results obtained while testing a number of patients, an online diagnostics method is envisaged to be developed for screening typical lung diseases using the database of odours.

Important tasks would also be to develop a conception of the instrument for online diagnostics of expired breath and to find most suitable types of sensors for screening procedures.

\section{EXPERIMENTAL}

The basic experiments were performed with a Nordic Sensor AB (Linköping, Sweden) electronic nose. This instrument contains 14 sensors: ten are MOSFET sensors with different gas sensing electrodes (Pt, Pd, Ir and their alloys) and working temperatures $\left(115{ }^{\circ} \mathrm{C}\right.$ and $\left.150{ }^{\circ} \mathrm{C}\right)$, and four are resistive high-temperature $\left(\sim 350{ }^{\circ} \mathrm{C}\right) \mathrm{SnO}_{2}$ gas sensors (Taguchi Gas Sensors - TGS-813; 800; 881; 825). The odour sampling was made using a small membrane pump connected to the sensors. In all measurements a sampling capability of $8 \mathrm{ml} / \mathrm{min}$ was used.

We have run three series of experiments, with a weekly interval between them. In the first series of experiments the sample collection was performed using $10 \mathrm{ml}$ plastic syringes. In the second and third series of measurements for sample collection 1.51 plastic packages were employed. As shown below, the method of collection did not affect the results of identification. Breath collection is the most important problem to be solved in experiments with electronic noses. In our preliminary tests we used short sampling time for only one exhalation - in total $10 \mathrm{ml}$ (a syringe) or 1.51 (a plastic package) thus making no inconvenience for patients during a test. To remove superfluous smells before the test, the patients rinsed the mouth and throat with water.

The headspace analysis was taken from patients during one exhalation and collected in special plastic bags (1.5 1 lavsan baking tubes). A breath sample was 
taken into the e-nose within $40 \mathrm{~s}$, at a pumping rate of $8 \mathrm{ml} / \mathrm{min}(5.2 \mathrm{ml}$ of gas was needed for the analysis during one measurement cycle, see Fig. 1).

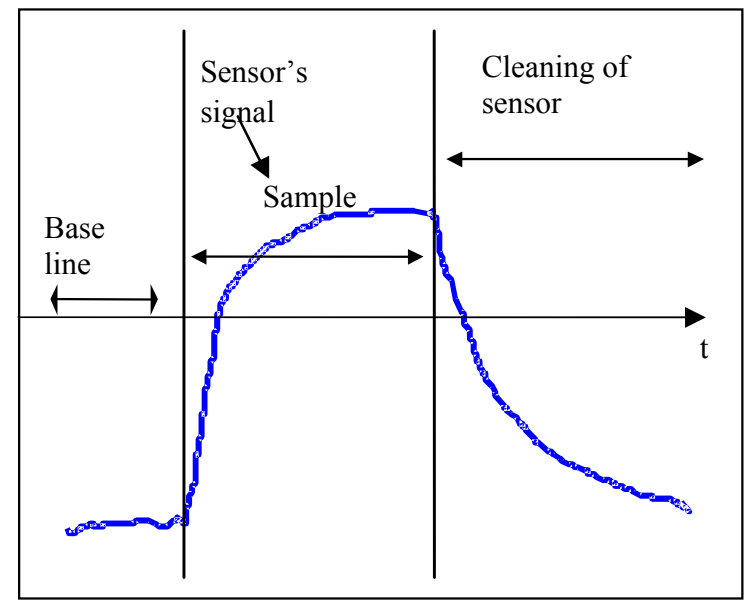

Fig. 1. Scheme of the sensor control. The base line time interval $-10 \mathrm{~s}$ from the start, the signal recovery time $-40 \mathrm{~s}$, and the time of cleaning the sensor $-70 \mathrm{~s}$.

Some samples were measured in 6 or 9 cycles in order to determine the possible odour area in the PCA (Principal Components Analysis) plot, but most of the analyses were taken in one cycle only. In the recognition analyses typically one cycle was used for an unknown sample to limit the time of analysis. The collected sample of expired breath was simultaneously investigated by the e-nose and fast gas chromatograph zNose ${ }^{\mathrm{TM}}$ (Model 4100, USA, EST Inc.). In this chromatograph only a small gas volume is necessary for the analysis (with a pumping rate $\sim 1 \mathrm{ml} / \mathrm{min}$ ). The carrier gas was helium, the column was quite short (1 m only), therefore the analysis time was also short - around 30-40 s. High sensitivity of $\mathrm{zNose}^{\mathrm{TM}}$ was achieved by using a surface acoustic wave sensor. Between the measurements of samples taken from different patients, cleaning of both the instruments was performed using room air cleaned by activated coal.

\section{RESULTS AND DISCUSSION}

In total, 66 individuals - 23 with asthma, 3 with COPD (chronic obstructive pulmonary disease), 12 with pneumonia, 13 with lung cancer, 4 in the past operation state (removed lung cancer) and 11 healthy volunteers were tested at two different times. The first analysis was made based on the e-nose measurements using the responses of all sensors. The artificial neural network (ANN) analysis was employed to classify the samples of cancer and other lung diseases. In this study, a back propagation network with a sigmoid transfer function was applied. The ANN analysis performance was estimated using the test set for one selected patient (P1) with bronchial asthma (measured more than once in the last session). A recognition example is shown in Fig. 2.

Another prediction model was developed using the response signals from two MOSFET sensors only for patients with cancer before and after operations. The logistic regression analysis splits all observations into two classes with the probability of error $p<0.0000312$ (Fig. 3). 


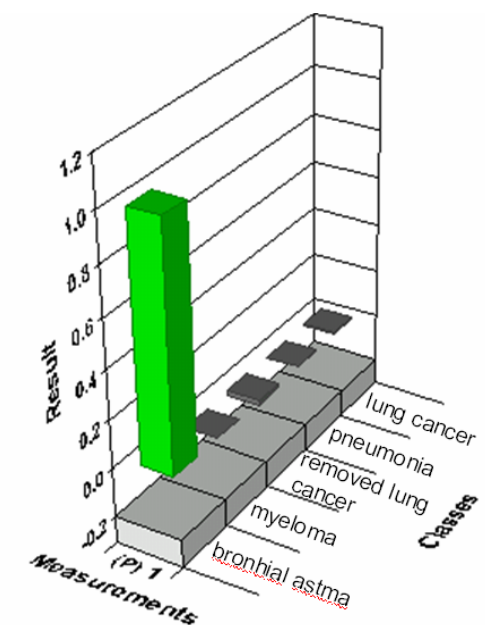

Fig. 2. ANN recognition pattern of selected patients.

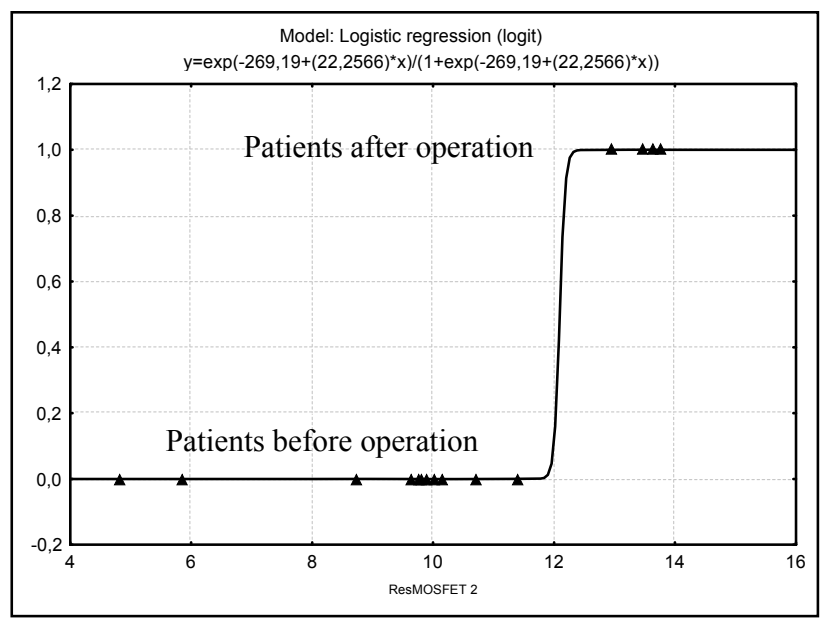

Fig. 3. Comparative prediction model for the patients with lung cancer before and after operation.

The results with gas chromatograph indicate some characteristic peaks of specific volatile organic compounds found for most of the patients with lung cancer. To date, it is unknown what volatile compounds are responsible for producing responses of e-nose sensors. We suggest that these sensors are responding to the combined effects of microbial metabolites and volatile cellular compounds in the breath of patients. The most important results have been obtained by discriminant analysis (Table 1).

As is seen from the classification matrix (Table 1), asthma $G_{-} 1$ was identified worst, while chronic obstructive pulmonary disease G_2, pneumonia G_3, lung cancer $\mathrm{G} \_4$, healthy $\mathrm{G} \_5$ and past-operation $\mathrm{G} \_6$ (removed lung cancer) states have been identified correctly. The results are presented in the 2D graph of Fig. 4. In this figure, correct classification of cases is on the main matrix diagonal (the observed and predicted classifications coincide). From 23 cases of asthma only 19 are correctly classified, and 4 are to be readdressed to other classes (two cases of pneumonia, one case of asthma and one of healthy state (which means a false alarm in the case with a healthy patient). 
Classification Matrix

Patients: 1 - asthma, 2 - COPD (chronic obstructive pulmonary disease), 3 - pneumonia, 4 - lung cancer, 5 - healthy, 6 - past operation (removed lung cancer). Rows: observed classifications, columns: predicted classifications (Wilks' Lambda: 0.0023542; F $(200.109)=1.305371 ; p<0.0610)$.

\begin{tabular}{|l|c|c|c|c|c|c|c|}
\hline & Percent Correct & G_1 & G_2 & G_3 & G_4 & G_5 & G_6 \\
\hline G_1 & 82.61 & 19 & 0 & 2 & 1 & 1 & 0 \\
\hline G_2 & 100.00 & 0 & 3 & 0 & 0 & 0 & 0 \\
\hline G_3 & 100.00 & 0 & 0 & 12 & 0 & 0 & 0 \\
\hline G_4 & 100.00 & 0 & 0 & 0 & 13 & 0 & 0 \\
\hline G_5 & 100.00 & 0 & 0 & 0 & 0 & 11 & 0 \\
\hline G_6 & 100.00 & 0 & 0 & 0 & 0 & 0 & 4 \\
\hline Total & 93.94 & 19 & 3 & 14 & 14 & 12 & 4 \\
\hline
\end{tabular}

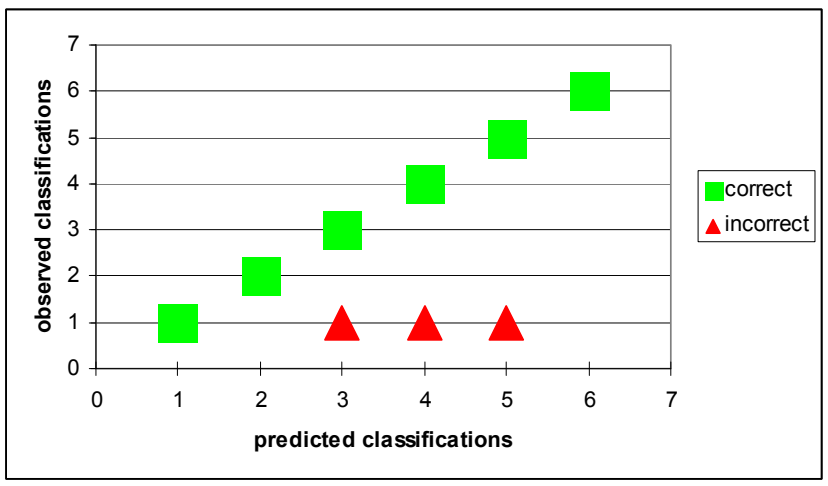

Fig. 4. Classification matrix for all patients: 1 - asthma, 2 - COPD (chronic obstructive pulmonary disease), 3 - pneumonia, 4 - lung cancer, 5 - healthy patients, 6 - past operation (removed lung cancer).

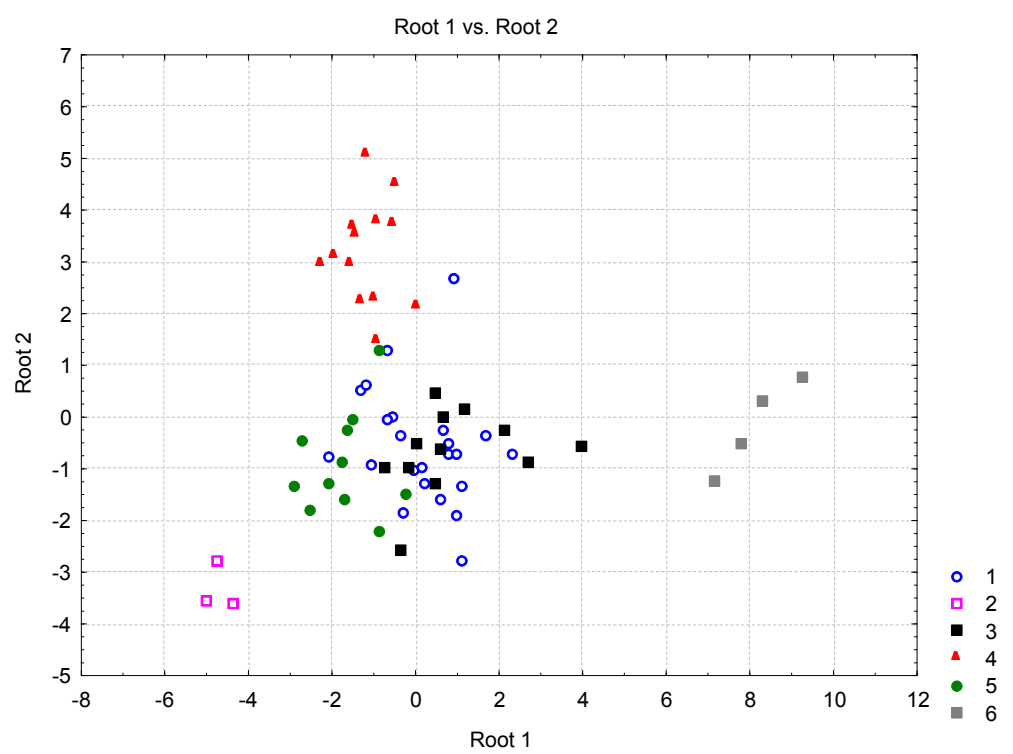

Fig. 5. Scatter plot of canonical scores. Patients: 1 - asthma, $2-$ COPD (chronic obstructive pulmonary disease), 3 - pneumonia, 4 - lung cancer, 5 - healthy patients, 6 - past operation (removed lung cancer). 
The scatter plot of canonical scores (Fig. 5) shows that the best discrimination is in the group 4 case (100\% lung cancer recognition).

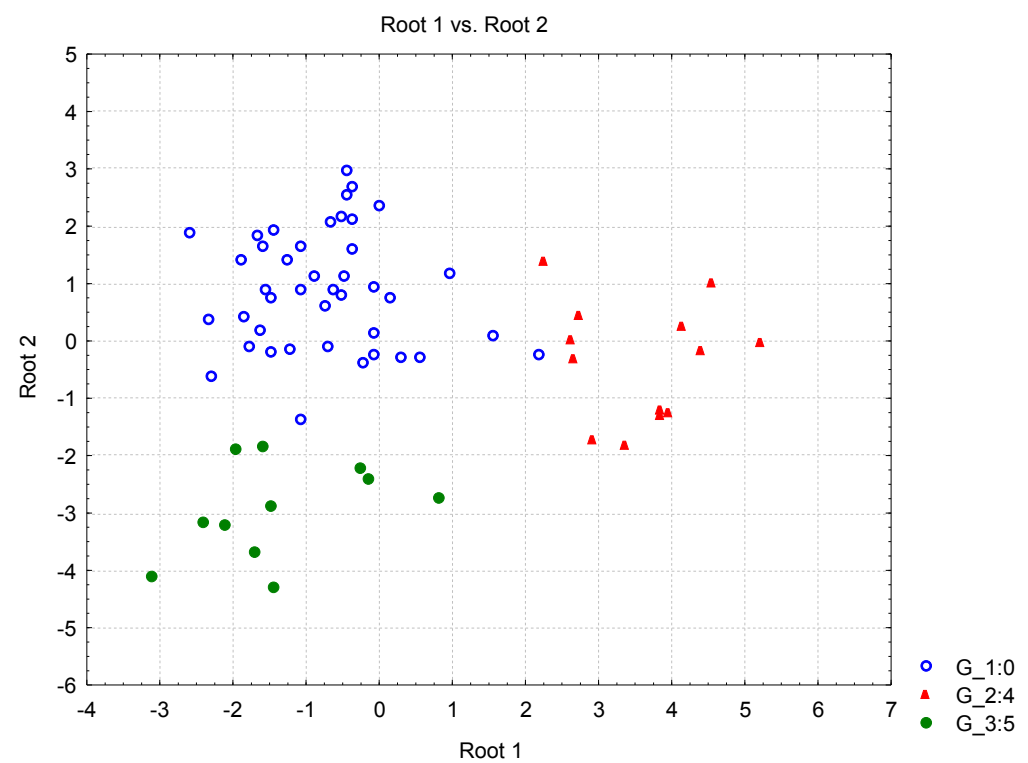

Fig. 6. Scatter plot of canonical scores. Patients: "G_1:0" - asthma, COPD (chronic obstructive pulmonary disease), pneumonia and past operation (removed lung cancer), "G_2:4" - lung cancer, "G_3:5" - healthy patients.

When the number of classes was reduced from 5 (ill and healthy patients) to 3 , a much better discrimination was achieved (see Fig. 6). In this case also the classification matrix of Table 2 is more suitable.

Table 2

Classification Matrix.

Patients: 0 - asthma, COPD (chronic obstructive pulmonary disease), pneumonia and past operation (removed lung cancer), 4 - lung cancer, 5 - healthy. Rows: observed classifications, columns: predicted classifications (Wilks' Lambda: 0.0744558; F (84.44) $=1.395849 ; p<0.1130$ ).

\begin{tabular}{|l|c|r|r|r|}
\hline & Percent Correct & G_0 & G_4 & G_5 \\
\hline G_0 & 95.24 & 40 & 1 & 1 \\
\hline G_4 & 100.00 & 0 & 13 & 0 \\
\hline G_5 & 100.00 & 0 & 0 & 11 \\
\hline Total & 96.97 & 40 & 14 & 12 \\
\hline
\end{tabular}

When only two classes are used a more perfect classification is possible. In Table 3 the results are presented for two classes when the first class includes asthma, COPD, pneumonia, lung cancer and past-operation states when cancer is removed, the second class - healthy patients. Table 4 contains data for the twoclass case when the first class includes asthma, COPD, pneumonia, healthy and past-operation states patients, and the second class - patients with lung cancer. 
Classification Matrix.

Patients: 0 - asthma, COPD (chronic obstructive pulmonary disease), pneumonia and past operation (removed lung cancer), lung cancer, 5 - healthy. Rows: observed classifications, columns: predicted classifications (Wilks' Lambda: 0.4027910; F $(28.37)=1.959252 ; p<0.0279)$.

\begin{tabular}{|l|c|r|r|}
\hline & Percent Correct & G_0 & G_5 \\
\hline G_0 & 100.00 & 54 & 0 \\
\hline G_5 & 100.00 & 0 & 12 \\
\hline Total & 100.00 & 54 & 12 \\
\hline
\end{tabular}

\section{Classification Matrix.}

Table 4

Patients: 0 - asthma, COPD (chronic obstructive pulmonary disease), pneumonia, healthy and past operation (removed lung cancer), 4 - lung cancer. Rows: observed classifications, columns: predicted classifications (Wilks' Lambda: 0.2318870; F (41.24) = 1.938992; $<$ 0.0435).

\begin{tabular}{|l|c|r|r|}
\hline & Percent Correct & G_0 & G_4 \\
\hline G_0 & 98.11 & 52 & 1 \\
\hline G_4 & 100.00 & 0 & 13 \\
\hline Total & 98.48 & 52 & 14 \\
\hline
\end{tabular}

\section{CONCLUSIONS}

In the work it has been shown that the lung cancer can easily be discriminated from other lung diseases during a short (less than $1 \mathrm{~min}$ ) breath sampling and analysis time. The volatiles produced by cancer make the greatest contribution to the responses of different e-nose sensors. To further develop this approach, new screening and monitoring methods should be created.

\section{ACKNOWLEDGMENTS}

Financial support from the ESF (European Social Fund) and University of Latvia is gratefully acknowledged. We are also grateful to the patients and medical personnel of the Department of Lung s Diseases of P. Stradina Hospital (Riga).

\section{REFERENCES}

1. Gardner, J.W., \& Bartlett, P.N. (1994). A brief history of electronic noses. Sens. Actuators, B 18, 210-220.

2. Ferguson, M.K. (1990). Diagnosing and staging of non-small cell lung cancer. Hematol. Oncol. Clin. North Am., 4,1053-1068.

3. Fontana, R.S., Sanderson, D.R., Woolner, L.B., et al. (1991). Screening for lung cancer. A critique of the Mayo Lung project. Cancer, 67, 1155-1164.

4. Di Natale, C., Macagnano, A., Martinelli, E., et al. (2003). Lung cancer identification by the analysis of breath by means of an array of non-selective gas sensors. Biosens. Bioelectron., 18, 1209-18.

5. Machado, R.F., Laskowski, D., Deffenderfer, O., et al. (2005). Detection of lung cancer by sensor array analyses of exhaled breath. Am. J. Respir. Crit. Care Med., $171,1286-1291$.

6. Mazzone, P., Hammel, J., Dweik, R., Na, J., Czich, C., Laskowski, D., \& Mekhail, T. (published online 27 Feb 2007). Lung Cancer Diagnosis by the Analysis of Exhaled Breath with a Colorimetric Sensor Array. THORAX; doi:10.1136/thx.2006.072892. 
7. Preti, G., Labows, J.N., Kostelc, J.G., et al. (1988). Analysis of lung air from patients with bronchogenic carcinoma and controls using gas chromatography-mass spectrometry. J. Chromatogr., 432, 1-11.

8. Phillips, M., Gleeson, K., Hughes, J.M.B., et al. (1999). Volatile organic compounds in breath as markers of lung cancer: a cross-sectional study. Lancet, 353, 1930-1933.

\section{PLAUŠU SLIMĪBU IDENTIFIKĀCIJA AR ELEKTRONISKĀ DEGUNa PALĪDZĪBU}

V. Ogorodņiks, J. Kleperis, I. Taivans, N. Jurka, M. Bukovskis

\section{Kopsavilkums}

Šajā pārskatā mēs analizējām provizoriskos rezultātus, ko iegūst elektroniskais deguns ar daudzu gāzes sensoru (metāla oksīdu sensori un ķīmiski jutīgi tranzistoru sensori) palīdzību slimnīcā no pacientiem ar dažādām plaušu slimībām. Izmantojām dažādas statistikas analīzes metodes, lai atrastu korelāciju starp sensoru atbilžu amplitūdām un pacientu diagnozēm. Tika norādīts, ka plaušu vēzi var viegli atšķirt no citām plaušu slimībām, analizējot izelpu paraugus îsā laika periodā (mazāk par 1 minūti). Vēža iespaids izelpas paraugā dod lielāko daļu elektroniskā deguna dažādu sensoru atbildēs, tāpēc vēzi var identificēt ar augstu precizitāti.

06.10 .2008 . 